\title{
「過酷環境で活躍するソフトマテリアル」特集号 の企画にあたって
}

ゴムをはじめとする多くのソフトマテリアルが 産業機械・設備や自動車に使用されています。こ れらがなければ産業機械や自動車の円滑な動作は 困難であり，ソフトマテリアルがキーマテリアル であることは言うまでもありません，産業機械や 自動車の高性能化にともない, ソフトマテリアル の使用環境はより過酷になってきました。また， これまで使用されることのなかった過酷な環境に もソフトマテリアルの用途が広がっています.

ソフトマテリアルを代表するゴムは，過酷な化 学的あるいは物理的負荷が加わると劣化し, 物性 の低下や損傷が生じます。化学的負荷には有機溶 媒, 酸・アルカリ，オゾンなどとの接触が挙げら れます。一方, 物理的負荷には, 高低温, 高低圧, 高電界, 紫外線, 高放射線への暴露などが挙げら れます。高温下では酸化によるゴム分子の切断や 再結合が生じ，ゴムの軟化や硬化が顕著になりま す。ガラス転移温度以下の低温ではゴム弾性が失 われます。高圧ガスに暴露されたゴムは，急減圧 によりブリス夕破壊が生じることが知られていま す。低圧下では，配合した低分子成分が揮発し， ゴムの機能が徐々に失われます。高電界下では放 電が生じ, 電気絶縁性が低下します。放射線にゴ ムが暴露されるとゴム分子の切断が生じ，物性低 下が著しくなります。さらにほとんどの過酷環境 ではこれらの負荷が複合して働き, 物性の低下や 損傷がより顕著になります。今後も産業機械や自
動車の性能向上や用途の拡大にともない, ソフト マテリアル製品はより一層過酷な環境で機能を発 揮することが求められるでしょう。そこで, 本誌 では「過酷環境で活躍するソフトマテリアル」に ついて特集することに致しました。

まず，石油や天然ガスの掘削や探査などの現場 で高温高圧用のシール材として活躍が期待される カーボンナノチューブ複合ゴムについて解説して いただきました。次に次世代のエネルギーキャリ アとして有望な高圧水素ガスに暴露された時のゴ ム製シール材の破壊現象について解説していただ きました。続いて, 宇宙環境特有の高低温, 紫外 線, 原子状酸素に暴露されたときのソフトマテリ アルの劣化モードや宇宙環境を模擬した試験と研 究事例について解説していただきました。さらに， 電力系統や鉄道など高電圧でかつ污損の激しい屋 外であっても電気絶縁機能を発揮するポリマーが いしについて解説していただきました。最後に高 い放射線レベルの環境でも使用が可能なゴムにつ いて解説していただきました。

過酷環境で機能を発揮するソフトマテリアルは, ゴム技術の発展に大きく寄与すると思われます。 本特集号に玉稿をお寄せ下さった著者の方々に厚 く御礼申し上げます。本特集号が会員皆様のお役 に立てれば幸甚です。

(編集委員会・特集企画担当 鈴木清宏) 